\title{
Teachers' stories on sense of belonging in co-teaching relationship
}

Henri Pesonen (Corresponding author)

Faculty of Educational Sciences, University of Helsinki, Helsinki, Finland

P.O. Box 9, Siltavuorenpenger 5, 00014 University of Helsinki, Finland.

henri.pesonen@helsinki.fi

Telephone: +358 503111944

\section{Anna Rytivaara}

Faculty of Education and Culture, Tampere University, Tampere, Finland

Åkerlundinkatu 5, 30014 Tampere University, Finland.

anna.rytivaara@tuni.fi

Telephone: +358 503186968

Orcid-ID: 0000-0003-4764-4412

\section{Iines Palmu}

Valteri Centre for Learning and Consulting, Mikkeli, Finland

Valteri Mikael, P.O. Box 102, 50049 VALTERI, Finland.

iines.palmu@valteri.fi

Telephone: +358 295332014

Orcid-ID: 0000-0002-6599-8743

\author{
Anna Wallin \\ Faculty of Education and Culture, Tampere University, Tampere, Finland \\ Åkerlundinkatu 5, 30014 Tampere University, Finland. \\ anna.wallin@tuni.fi
}

Telephone: +358 503187578

Orcid-ID: 0000-0002-5893-133X 


\title{
Teachers' stories on sense of belonging in co-teaching relationship
}

\begin{abstract}
The aim of this article was to examine primary school teachers' perceptions about their sense of belonging in co-teaching. We were particularly interested in investigating the factors which enhance or hinder teachers' sense of belonging in their co-teaching relationships. The data were collected using the method of empathy-based stories (MEBS) consisting of frame stories with a variation in whether a co-teaching situation was experienced as positive or negative. Qualitative analysis of the stories revealed that teachers' sense of belonging was constructed through three dimensions: 1) teachers' work practices, 2) mutual relationship, and 3 ) individual characteristics. The findings contribute to the literature by demonstrating that a sense of belonging in co-teaching is a multidimensional phenomenon that is built in a close collegial relationship between teachers. The study adds a new micro-level perspective on how teachers' sense of belonging is constructed between two co-teachers.
\end{abstract}

Keywords: co-teaching; co-teaching relationship; sense of belonging; teacher stories, method of empathy-based stories

\section{Introduction}

Successful co-teaching is based on teachers' mutual and collegial relationship (Pratt 2014; Rytivaara, 2012). A co-teaching relationship comprises characteristics such as mutual respect for a colleague’s professional knowledge, skills and experience (Rytivaara, Pulkkinen, \& de Bruin, 2019). Some scholars have compared this relationship to marriage due to its nature of learning to work together and accept the characteristics of their colleague (see Howard \& Potts, 2009; Murawski, 2008). Thus, it is not surprising that the greatest challenge teachers experience regarding co-teaching is related to the relationship with their co-teaching partner rather than actual teaching (see e.g., Fluijt, Bakker, \& Struyf, 2016). 
The characteristics of co-teaching relationship appear to be close to a teacher's sense of belonging at work, such as feeling accepted, supported and respected by a colleague (e.g., Baumeister \& Leary, 1995; Nislin \& Pesonen, 2018). Teachers with a strong sense of belonging in their immediate working environment have a better overall level of well-being (e.g., Juvonen, 2006; Skaalvik \& Skaalvik, 2011) and motivation (e.g., Osterman, 2000). Moreover, teachers with a strong sense of belonging can enhance a school climate that supports children’s sense of belonging (Juutinen, 2018; Pesonen, 2016). However, while sense of belonging has been explored among schoolaged children (e.g., Fredrickson, Simmonds, Evans, \& Soulsby, 2007; Furrer \& Skinner, 2003; Lindsay, 2007; Schnorr, 1997; Williams \& Downing, 1998) and university students (e.g. Freeman, Anderman, \& Jensen 2010; Gizir, 2018; Hoffman, Richmond, Morrow, \& Salomone, 2002), the few studies on teachers have focused on their sense of belonging within teachers’ wider working environment (Skaalvik \& Skaalvik, 2011; Nislin \& Pesonen, 2018). Thus, literature on teachers’ sense of belonging in collegial relationships is scarce.

To fill this research gap, the purpose of this study is to examine how teachers' sense of belonging is constructed in collegial relationships. We focused on primary school teachers' perceptions about their sense of belonging in co-teaching. The data were collected using the method of empathy-based stories (MEBS) (Wallin, KoroLjungberg, \& Eskola, 2018) to address the following questions:

(1) Which factors enhance teachers' sense of belonging in co-teaching relationships?

(2) Which factors hinder teachers' sense of belonging in co-teaching relationships?

By examining teachers' stories on their co-teaching practices, our study illustrates how teachers' sense of belonging is constructed through these relational practices. Moreover, 
the findings from this new context, co-teaching, will add to the theoretical model of teachers' sense of belonging. The study will also provide practical implications about relational school practices which can improve teachers' sense of belonging not only in co-teaching but also in a wider school community.

\section{Teachers' sense of belonging}

Sense of belonging refers to the extent to which an individual feels socially connected, respected, accepted, supported and included by other people in various social contexts (Baumeister \& Leary, 1995; Hagerty, Lynch-Sauer, Patusky, Bouwsema, \& Collier, 1992). In a school context, the concept refers to the extent to which teachers feel respected and supported by their colleagues. Sense of belonging is a basic human need (Maslow, 1962) and is essential to human motivation (see e.g., Deci \& Ryan, 2000). People want to be socially connected to other people and part of a group throughout life (e.g., circle of friends, family, colleagues). People who have close relationships with others and experience a sense of belonging perform better mentally and physically (Baumeister \& Leary, 1995; Juvonen, 2006; Pesonen, Kontu, Saarinen, \& Pirttimaa, 2015). On the contrary, the lack of a sense of belonging can cause serious illness (e.g., depression) (Juvonen, 2006; Pesonen et al., 2015; Pesonen, 2016).

As sense of belonging has mostly been studied from students’ perspectives (e.g., Faircloth \& Hamm, 2005; Freeman, Andermand \& Jensen, 2010; Furrer \& Skinner, 2003 Gizir, 2018; Hoffman et al., 2002; Pesonen, 2016), we adapted Juvonen’s model of students' sense of belonging at school as a conceptual framework in our study, along with earlier studies on teachers' sense of belonging at work (e.g., Skaalvik \& Skaalvik, 2011). Figure 1 depicts our conceptual model, which involves teachers’ (1) relationships with colleagues, (2) relationship with the school climate, and (3) relationships with leadership. 


\section{[FIGURE 1 HERE]}

Figure 1. A model of teachers' sense of belonging depicting the association between relationships with colleagues, leadership, school climate, and sense of belonging. (Adapted from Juvonen, 2006, p. 668).

The model suggests that teachers' sense of belonging to the school climate refers to them feeling like a part of the school and its values (Goodenow, 1993; Skaalvik \& Skaalvik, 2011), feeling accepted and respected by school staff and students, as well as feeling proud of belonging to the school as a workplace (Goodenow, 1993). For example, if the teachers do not share the values of their school, they might experience challenges in their sense of belonging (Juutinen, 2018). Moreover, teachers might not feel respected by their colleagues or students (see Goodenow, 1993). This can jeopardize their sense of belonging.

Relationships with leadership refer to teachers’ experiences of receiving cognitive and emotional support from their principals, which is related to better job satisfaction, commitment to their profession and wellbeing (Berkovich \& Eyal, 2018; Littrell et al.,1994; Russell, Altmaier, \& Van Velzen, 1987). For example, support can mean that teachers feel they can always ask for help from their principals (e.g., with distribution of resources, issues with students) and that the principal values, trusts and respects their work, and listens to teachers’ concerns. Principals should master ongoing and supportive communication with their teachers (Berkovich \& Eyal, 2018).

Respectful and warm relationships and trust among colleagues are fundamental for a teacher's sense of belonging (Skaalvik \& Skaalvik, 2011). Their study further suggests that collegial support, trust and respect predict a teacher's sense of belonging and job satisfaction, whereas a lack of positive relationships with other teachers can 
lead to a lower sense of belonging. In turn, this can cause emotional exhaustion that can have a negative effect on job satisfaction. For teachers to feel a sense of belonging with their colleagues, these relationships need to be based on mutual trust and respect so that teachers feel they can be themselves, as well as being valued and accepted (e.g., Goodenow, 1993; Hagerty et al., 1992). Through collegial relationships, teachers can also support each other pedagogically (Rytivaara \& Kershner, 2012).

The same characteristics, which enhance teachers' sense of belonging in their collegial relationships, appear in descriptions of good co-teaching relationships. Coteaching can be defined as a mutual relationship of two or more teachers who plan, implement and assess teaching a group of students together (Fluijt et al., 2016; Malinen \& Palmu, 2017). Research indicates that for co-teaching to be dynamic and successful, teachers need to share an open, respectful and caring relationship (Pratt, 2014; Rytivaara et al., 2019). For co-teachers, these collegial relationships form their immediate work community, in which they should be respected, supported and accepted by colleagues to experience a sense of belonging (e.g., Goodenow, 1993; Juutinen, 2018; Nislin \& Pesonen, 2018). However, earlier scholarly work has not included studies on teachers' sense of belonging within these relationships.

\section{Methods}

\section{Participants and data collection}

We collected the data from 38 primary school teachers at two schools in two small cities in Eastern Finland during November and December 2018 using the method of empathybased stories (MEBS). MEBS is a qualitative data collection method in which participants write short imaginary writings based on a frame story provided by the researcher. MEBS was originally developed in the 1970s in the United States, when it 
was referred to as passive or nonactive role-playing (Eskola, 1988). It was modified from active role-playing used in psychology and social psychology in order to study how the participants interpret different situations (Mixon, 1972; see also Eskola, 1998; Ginsburg, 1978, 1979). Experimental studies received in the 1960s and 1970s critique about the use of deception in research, and this discussion prompted researchers to develop optional research methods such as MEBS (Ginsburg, 1978).

MEBS uses at least two frame story versions, which differ in respect to one aspect. This variation enables the researcher to study how the participants' stories change when one element is varied. Usually the frame stories describe an event or situation, and the participants are instructed to continue the story or explain what has happened before the situation described (Wallin et al., 2018). MEBS research has been conducted in many different research fields and contexts, and frame stories can be constructed in multiple ways (Wallin et al., 2018). For instance, MEBS has been used to explore how a concept or a phenomenon is conceptualised, as in a study on the dominant discourses of green consumerism (Moisander \& Pesonen, 2002), or to study what factors are related to a less known phenomenon as in Kultalahti's (2015) study on Millennials’ work-related motives and preferences.

This study involved two frame stories with a variation in whether a co-teaching situation was experienced as being positive or negative:

(1) You are teaching with another teacher. You feel comfortable in the situation and you experience the presence of the colleague as positive. Describe the situation and your thoughts in more detail.

(2) You are teaching with another teacher. You feel uncomfortable in the situation and you experience the presence of the colleague as negative. Describe the situation and your thoughts in more detail. 
MEBS produces data which describe participants’ perceptions, expectations, sociocultural representations and mental images regarding some phenomenon. Hence, as MEBS does not focus on researching actual lived experiences, the stories portray plausible and possible connections and insights, which are based on the participants' own imagination (Wallin et al., 2018). It is important to note, that empathy-based stories “do not tell 'the truth'” or the true state of events or past actions and behaviours, but rather the possibilities, hopes, threats, and values people associate with different phenomena and experiences” (Wallin et al., 2018, 7). However, this imaginative aspect of MEBS does not mean that the stories are merely fictional; they are often based on culturally shared meanings (Wallin et al., 2018). Thus, theoretically MEBS follows constructivist and relativist epistemologies in which reality is contextually and socially constructed, and reality and narratives are assumed to reflect and imitate each other (Wallin et al., 2018; see also Berger \& Luckmann, 1984; Bruner, 2004; Eskola, 1998). The imaginative nature of MEBS made the method particularly suitable for this study as the imagined stories could provide new insights and perspectives about teachers' sense of belonging in co-teaching situations. Also, MEBS lacks face-to-face interaction, which may be an asset as it allows the participants to freely express themselves without adding any external pressures. For example, it has been found that in personal interviews interviewees are prone to give socially desirable answers (e.g. Janis, 1982; Krumpal, 2013; Schuman \& Presser, 1981; van der Heijden et al., 2000). Additionally, MEBS is suitable for exploring situations new or unfamiliar to participants, which made the method suitable for this study as not all teachers in this study had long experience with co-teaching.

The data were collected in a professional development session led by one of the authors of this paper. The data were collected anonymously, and thus no background 
information was gathered. The participants at both schools ranged from newly-qualified to experienced teachers. Moreover, an estimated one-quarter of the teachers were special education teachers, the rest being general education teachers. In general, coteaching in Finland occurs most often between two classroom teachers or between a classroom teacher and a special education teacher (Saloviita \& Takala, 2018). Half of classroom teachers and over $60 \%$ of special education teachers co-teach at least once a week (Saloviita, 2018).

The teachers did not know about the data collection beforehand, but the principals of the schools were asked for general permission. Participation was voluntary. Only one potential participant declined. The participants were randomly given one frame story version on which they were to write their story. They were instructed to imagine how they would act and think in the described situation, and that they did not need to rely on their personal experiences in their stories. The teachers were given 20 minutes to write their stories either by hand or by computer. At the time of writing, the teachers were not aware of variants in frame stories but after handing in the papers, the teachers were told about the two versions and given a chance to share their thoughts. The procedure and the researcher was the same in each data collection situation.

\section{Data Analysis}

The data comprised 19 positive and 19 negative stories. The stories were distributed evenly between the schools (see Table 1.). The positive stories had an average of 77 words and the negative stories had 60 words. The teachers wrote the stories in Finnish, and the citations used in this article were translated into English. 
Table 1. Distribution of stories between schools

[TABLE 1 HERE]

We analysed the data using qualitative inductive content analysis (Elo \& Kyngäs, 2008; Merriam, 2009). In the first phase, the positive and negative stories were analysed separately. The positive stories were analysed according to RQ1 (the enhancing factors), whereas the analysis of the negative stories was guided by RQ2 (the hindering factors). After reading the stories multiple times, all stories were cut into sentence-long units according to the research questions guided by the theoretical framework, and sentences not related to the research questions were left out. Next, these sentence-long units were coded inductively and organised into sub-categories and further into generic categories. Finally, we organised the generic categories into two main categories, the enhancing and hindering factors. The enhancing and hindering factors, and the generic categories comprising them, are presented in Table 2.

In the second phase, we compared the enhancing and hindering factors. As a result of this abstraction process, we formulated the generic categories into three dimensions: teachers’ work practices, mutual relationship, and teachers’ individual characteristics (see Table 2). In the third phase, we constructed two example stories, one to illustrate a positive sense of belonging and one to illustrate a negative sense of belonging. The stories were constructed by selecting data extracts that described the main idea of each category. The extracts were organised into a coherent story following Polkinghorne's (1995) concept of narrative analysis, and a few words and phrases were added to improve readability. The frequencies in the table refer to the number of participants in each category. 
Table 2. Comparison of the categories.

[TABLE 2 HERE]

For the purposes of ensuring the trustworthiness of the study, we used researcher triangulation (Patton, 2015 p. 665-667) throughout the analysis. First, the author who initially analysed the data, frequently discussed the codes and categories with the coauthors. Second, all authors had a data validation meeting (Given, 2008) at which all the initial codes, their organisation into sub-categories and further into generic categories were checked and discussed until consensus was reached. Finally, the example stories were approved by all authors.

\section{Findings}

According to the stories, teachers' sense of belonging in co-teaching comprised three dimensions: teachers’ work practices, teachers' mutual relationships, and teachers’ individual characteristics. These dimensions were present in both the positive and negative stories and are shown below in the enhancing and hindering sections, respectively. Both sections have been illustrated with an example story, followed by a closer examination of the enhancing and hindering factors of co-teachers' sense of belonging. The original excerpts are enclosed in quotation marks, and the categories are shown in italics.

\section{Factors enhancing co-teacher's sense of belonging}

We adequately planned our session beforehand. We have a clear division of work and roles and we share the responsibility equally. We know and respect each other's way of working and teaching, and can use our strengths. It is easy for us to work together because we have a similar understanding of learning, values and classroom rules. There is no tension between us, but we can discuss everything, and we are understanding/ empathic towards each other. We give room to each 
other. We encourage and support each other in tough moments rather than being arrogant or self-conscious.

The first dimension, teachers' work practices, included three factors that the teachers perceived as enhancing their sense of belonging in co-teaching: planning, division of work and shared responsibilities and commitment. In particular, the teachers emphasised that in successful co-teaching, co-taught lessons were 'planned together' (P3) and 'with the colleague' (P5) so that they 'both have gone through the guidelines' (P6). Sharing the responsibilities and commitment lightened their emotional workload in good and bad moments. It was both 'delightful not having to plan and ponder everything alone' (P19), but the teachers also emphasised that whatever happened in the classroom, the teachers would support each other in the situation: 'If we blunder, we blunder together' (P18).

Regarding the second dimension, mutual relationship, four factors enhanced teachers' sense of belonging. First, the relationship was based on teachers knowing each other, indicating they '[knew] each other's ways of working' (P10) and 'can tell how the other one is feeling/ what the other one is thinking' (P4). Second, teachers' mutual relationship was characterised by respect and trust, and teachers described it as ‘seamless collaboration' (P9). This also meant that while teachers 'trust[ed] each other' (P6), they also respected each other as professionals. Thus, it was accepted that their 'colleague can do things differently from me' (P5) and that they had 'differences in thinking' (P4). Seven teachers mentioned 'trust' in their stories, and as such it was the most frequently appearing single factor describing teachers' sense of belonging in coteaching. Third, teachers' relationships were also characterised by collegial support in various situations. Teachers 'encouraged [and] supported each other' (P10), and this was particularly valued ‘in conflict situations or moments of insecurity' (P1) or 'if 
there’s a problem with a student' (P17). As one teacher summed it up: ‘two teachers means [I am] feeling less inadequate’ (P16). The fourth factor related to teachers' mutual relationship was the atmosphere. The teachers described this relaxed and positive drive they had by how 'there is no tension between us' (P2), 'sense of humour blossoms’ (P8) and '[one’s] enthusiasm influences the other’ (P4).

The third dimension of teachers' sense of belonging within their co-teaching team was related to teachers' individual characteristics. The first enhancing factor in this dimension was similarity of pedagogical thinking. Teachers emphasised that having ‘similar styles in instructing and guiding/ supervising students' (P2) and having ‘a common/ joint/ shared, clear goal' (P1) made them experience co-teaching as a joint effort. The focus of their relationship was on 'learning processes' (P14), and thus 'sharing the same aims/ goals' (P8) made teachers 'satisfied with one’s work' (P1). The second factor which enhanced teachers' sense of belonging was use of individual strengths. The teachers emphasised that 'acknowledging their own and the other teacher's strengths and weaknesses' (P10) allows teachers 'to use their own strengths' (P5). This, furthermore, makes teachers 'experience success’ (P1).

In sum, the positive stories about teachers' sense of belonging in co-teaching were filled with positive expressions about their co-teaching ['shared'/ 'common'/ 'joint'] and indicated that the teachers were heading to the same direction with their pedagogical views. Most important, the stories indicated that the co-teachers working together were in a warm and supportive relationship, enjoying their professional partnership.

\section{Factors hindering co-teacher's sense of belonging}

As I enter the classroom, my colleague has already started the lesson and ignores me totally. As it comes to my turn to teach, the colleague criticises aloud my way 
of teaching. Thus, instead of teaching, I focus on my colleague observing me and I lose my words. I feel anxious because what we're doing doesn’t feel right to me. Neither do I feel safe or comfortable during our joint session. It is common that we haven't discussed the division of work and I can’t anticipate what they are expecting from me, or if we have agreed on a lesson plan, they decide not to follow it. We constantly disagree on pedagogical issues and student assessment.

The first dimension, teachers' work practices, included two factors that hindered teachers' sense of belonging in co-teaching: first, not discussing/ agreeing on practical matters, and second, not following matters already agreed on. The stories emphasised how lack of discussion, lack of common planning and lack of agreement complicated teachers' sense of belonging in relation to their co-teaching team. Another factor was a colleague's active anticipation to stick to the plans the teachers had made together. For example, ‘without further notice’ (N16) or ‘without a pedagogical reason’ (N14) one 'would change plans as she or he wishes' (N16).

The teachers' stories also showed two factors related to teachers' mutual relationship, discomfort and lack of mutual respect, which hindered teachers' sense of belonging in their co-teaching teams. Discomfort was illustrated by situations described as 'unnatural' (N10) and 'awkward' (N10) and in which a teacher was 'feeling nervous, becoming irritated' (N7). In these situations, teachers were 'afraid to do something wrong' (N20) or 'to be misunderstood, again' (N4). The second factor, lack of mutual respect, was about co-teacher 'ignoring' (N3) the other teacher completely during a lesson. Mutual respect was also missing in situations in which either 'a younger colleague [- - - had proved to be a know-it-all' (N20) or a colleague had 'very strong opinions [- - - ] with years of experience' (N8). Such situations made the other teacher feel '[his/ her] professional skills are not valued' (N11).

The third dimension of teachers' sense of belonging was about teachers' individual characteristics; particularly the differences in their pedagogical thinking. As 
one teacher put it, 'Our ways of thinking do not match at all.' (N12) This mismatch hindered their sense of belonging as 'different views of what is considered good learning and teaching might cause negative feelings.' (N14).

In sum, the negative stories about teachers' sense of belonging within coteaching were filled with grammatical negatives and active anticipation of what could be considered as good collaboration. Teachers had 'not discussed' or 'not agreed' on matters regarding their co-teaching practices; a teacher 'cannot anticipate', 'do[es] not feel safe'; or a colleague ‘does not say hello' or ‘does not follow [what was agreed on together]'.

\section{Discussion}

This study examined teachers' perceptions of the factors that either enhance or hinder their sense of belonging in co-teaching relationships. Our study contributes to the literature on teachers’ sense of belonging (e.g., Skaalvik \& Skaalvik, 2011; Nislin \& Pesonen, 2018) by widening the perspective into co-teaching relationships and illustrating in detail how teachers' sense of belonging may be constructed in such close collegial relationships. We discovered that co-teachers' sense of belonging was constructed through three dimensions: 1) teachers’ work practices, 2) mutual relationship, and 3) individual characteristics.

The teachers’ stories suggest that teachers' sense of belonging was constructed through joint practices and task-sharing, efforts on the professional relationship between the teachers, and by reflecting and sharing one’s pedagogical thinking. Interestingly, both sets of stories also shared a common feature related to students. Teachers' commitment to teaching their students was evident throughout the stories as none of the teachers described a situation in which a teacher was not working at all. Rather, in negative stories, the ignorance of the other teacher hindered teachers' sense of 
belonging. Another noteworthy issue was teachers' strong focus on their mutual relationship, students being nearly inconspicuous in most stories.

\section{Theoretical and practical contributions}

Although the findings of this study are in line with the earlier literature (e.g., Baumeister \& Leary, 1995; Goodenow, 1993; Hagerty et al., 1992; Juutinen, 2018; Juvonen, 2006; Nislin \& Pesonen, 2018; Pesonen, 2016; Pesonen et al., 2015; Skaalvik \& Skaalvik, 2011), our findings add new perspectives on understanding and fostering teachers' sense of belonging in co-teaching relationships. First, in our theoretical model of teachers' sense of belonging (see Figure 2), we emphasise the seamless mutual relationship with the co-teaching colleague. In our model, the co-teaching relationship consists of knowing each other well, sharing values and beliefs, as well as feeling respected, accepted and supported by the colleague (e.g., Goodenow, 1993; Hagerty et al., 1992; Juutinen, 2018). Second, as depicted in Figure 2, the model should consider teachers' work practices that consist of an agreed division of work, shared planning, responsibilities, and commitment to work (Malinen \& Palmu, 2017; Rytivaara et al., 2019).

Finally, our findings showed that teachers' individual characteristics, such as similar pedagogical thinking and practical knowledge, need to be addressed in the model of teachers' sense of belonging. In particular, co-teachers need to reflect on their own thinking and ways of working to negotiate a shared way of working in which both teachers feel comfortable (Fluijt, Bakker, et al. 2016; Shin, Lee, \& McKenna, 2016). Thus, in co-teaching relationships, communication and shared pedagogical guidelines are essential for teachers to enhance their sense of belonging. 
Figure 2. Dimensions associated with co-teachers’ sense of belonging

Our findings encourage practitioners and teacher educators to pay attention to individual and team reflection skills to give teachers tools to develop their sense of belonging and thus successful co-teaching teams. Furthermore, student teachers could practice co-teaching and team reflection in teaching practicums by utilising the three dimensions of teachers' sense of belonging.

Experienced teachers need more opportunities to practice co-teaching and learn to know their 'co-teacher qualities' to construct sense of belonging. The purpose of planning time is not only to discuss lesson plans, but also to reflect on the shared responsibilities and the current state of the mutual relationship, for example whether the teachers agree how responsibilities are shared within their co-teaching partnership. Hence, communication between the teachers is in the core of co-planning. Moreover, teachers should also discuss what they mean by 'co-teaching' and what implications this has in their co-teaching relationship, as well as in the classroom. Teachers need to negotiate, for example, what kind of roles each has in co-taught lessons and how much time they are willing to spend on building their co-teaching partnership and practices. Similarly, if teachers' visions of good teaching and pedagogy do not match in the beginning of co-teaching partnership, they might try starting with clearly structured lessons plans where their roles and divisions of work is considered in detail (e.g., Rytivaara et al., 2019).

Principals are in charge of creating and maintaining a positive, collaborative work environment. They can play a fundamental role in developing a vision about collaborative working culture, hire staff who are committed to this vision, provide staff development based on shared values, as well as create space for teacher collaboration and sharing responsibilities among the staff members. In such a collaborative culture 
co-teaching is supported and encouraged by the whole school community (e.g., Ainscow, Dyson, \& Weiner, 2014).

\section{Limitations and future research}

This study has its limitations. Regarding the transferability of the findings from a small qualitative data set, the reader has to be cautious when applying the results to other contexts. Furthermore, the participating teachers' backgrounds and varying amount of co-teaching experience need to be considered when interpreting the findings and planning future studies. Additionally, one limitation or rather a feature of this study concerns the nature of the data on which it was based. MEBS was chosen as a data collection method in this study to examine the participants' perceptions and views, and thus to find new perspectives on the topic. Hence, as empathy-based stories are imaginative stories, it is important to highlight that the findings describe potential connections and insights on the topic and do not necessarily reflect the participants' actual lived experiences of co-teaching. However, the similarity of the stories and the fact that the findings of this study are in line with earlier studies supports the notion that the stories describe shared socio-cultural beliefs and perspectives, which may be based on the participants' own experiences. Nonetheless, in the future, more comprehensive data will be needed to complement and replicate the findings of this study and to validate the model proposed.

More studies are also needed to explore how sense of belonging is constructed in the relationships between teachers who are not co-teaching, as well as between teachers and their principals. For example, what is the role of the cognitive and emotional support teachers receive from their principals (e.g., Berkovich \& Eyal, 2018; Skaalvik \& Skaalvik, 2011) in relation to the support teachers receive from their colleagues. Another interesting topic would be to study students' sense of belonging in a co- 
teaching context. Larger data sets would have the potential to bring out more generalizable conclusions, as well as to add multidimensional perspectives to the model proposed in this study. It could also shed light on how different dimensions of sense of belonging are related to each other, to what extent all factors need to be present, and how they balance each other out.

Our study demonstrated that a sense of belonging in co-teaching is a threedimensional phenomenon built in a close collegial relationship between teachers. The study also adds a new micro-level perspective on how a teacher's sense of belonging is constructed between two co-teachers. Thus, we conclude by saying that to develop successful co-teaching teams, all three dimensions need to be considered and balanced, which also requires principals to pay attention to how they support their teachers.

\section{References}

Ainscow, M., Dyson, A., \& Weiner, S. (2014). From Exclusion to Inclusion. A review of international literature on ways of responding to pupils with special educational needs in schools. Retrieved from http://rabida.uhu.es/dspace/bitstream/handle/10272/8169/De_la_exclusion_a_la_ inclusion.pdf?sequence $=2$

Baumeister, R. F., \& Leary, M. R. (1995). The Need to Belong: Desire for Interpersonal Attachments as a Fundamental Human Motivation. Psychological Bulletin, 117, 497-529.

Berger, P. L., \& Luckmann, T. (1984). The Social Construction of Reality: a Treatise in the Sociology of Knowledge. Harmondsworth: Penguin.

Berkovich, I. \& Eyal, O. (2018). Principals’ emotional support and teachers’ emotional reframing: The mediating role of principals’ supportive communication strategies. Psychology in the School, 55(7), 867 - 879.

Bruner, J. S. (2004). Life as Narrative. Social Research, 71(3), 691-710. 
Deci, E. L., \& Ryan, R. M. (2000). The "what” and "why” of goal pursuits. Human needs and the self-determination of behaviour. Psychological Inquiry, 11, 227 268.

Elo, S., \& Kyngäs, H. (2008). The qualitative content analysis process. Journal of Advanced Nursing, 62, 107-115. doi:10.1111/j.1365-2648.2007.04569.x

Eskola, A. (1988). Non-active Role-Playing: Some Experiences.” In Blind Alleys in Social Psychology: a Search for Ways Out, edited by A. Eskola, A. Kihlström, D. Kivinen, K. Weckroth, and O.-H. Ylijoki, 239-311. Amsterdam: NorthHolland.

Eskola, J. (1998). Eläytymismenetelmä sosiaalitutkimuksen tiedonhankintamenetelmänä [The Method of Empathy-Based Stories as a Method of Acquiring Data in Social Research]. Tampere: TAJU.

Faircloth, B. S., \& Hamm J. V. (2005). Sense of belonging among high school students representing four ethnic groups. Journal of Youth and Adolescence, 34(4), 293309. doi: 10.1007/s10964-005-5752-7

Fluijt, D., Bakker, C., \& Struyf, E. (2016). Team-reflection: The missing link in coteaching teams. European Journal of Special Needs Education, 31(2), 187-201. doi:10.1080/08856257.2015.1125690

Fredrickson, N., Simmonds, E., Evans, L., \& Soulsby, C. (2007). Assessing the social and affective outcomes of inclusion. British Journal of Special Education, 34(2), 105-115.

Freeman, T. M., Andermand, L. H., \& Jensen, J. M. (2010). Sense of Belonging in College Freshmen at the Classroom and Campus Levels. The Journal of Experimental Education, 75(3), 203-220. doi:10.3200/JEXE.75.3.203-220.

Friend, M. (2015). Co-teaching Defined. Retrieved from: http://www.marilynfriend.com/basics.htm.

Ginsburg, G. P. (1978). Role-playing and Role Performance in Social Psychological Research. In The Social Context of Method, edited by M. Brenner, P. Marsh, and M. Brenner, 91-121. London: Croomhelm.

Ginsburg, G. P. (1979). The Effective use of Role-Playing in Social Psychological Research. In Emerging Strategies in Social Psychological Research, edited by G. P. Ginsburg, 117-154. New York: John Wiley \& Sons. 
Given, L. M. (2008). The SAGE Encyclopedia of Qualitative Research Methods. Thousand Oaks, California: SAGE Publications Inc.

Gizir, S. (2018). The sense of classroom belonging among pre-service teachers: Testing a theoretical model. European Journal of Educational Research, 8(1), 87-97.

Goodenow, C. (1993). The Psychological Sense of School Membership among Adolescents: Scale Development and Educational Correlates. Psychology in the Schools, 30, 79-90. doi:10.1002/ (ISSN)1520-6807.

Hagerty, B. M., Lynch-Sauer, K., J. Patusky, K. L., Bouwsema, M., \& Collier, P. (1992). Sense of Belonging: A Vital Mental Health Concept. Psychiatric Nursing, 3, 172-177. doi:10.1016/0883-9417(92)90028-H.

Hoffman, M., Richmond, J., Morrow, J., \& Salomone, K. (2002). Investigating “sense of belonging” in first-year college students. Journal of College Student Retention: Research, Theory \& Practice. doi: https://doi.org/10.2190/DRYCCXQ9-JQ8V-HT4V

Howard, L., \& Potts, E. A. (2009). Using Co-Planning Time: Strategies for a Successful Co-teaching Marriage. TEACHING Exceptional Children Plus, 5 (4), 1-12.

Retrieved from: http://escholarship.bc.edu/education/tecplus/vol5/iss4/art2

Janis, I. L. (1982). Groupthink. 2nd ed. Boston: Houghton Mifflin.

Juutinen, J. (2018). Inside or outside? Small stories about the politics of belonging in preschools (Doctoral dissertation). Retrieved from http://jultika.oulu.fi/Record/isbn978-952-62-1881-6

Juvonen, J. (2006). Sense of Belonging, Social Bonds, and School Functioning. In P. Alexander and P. Winne (Eds), Handbook of Educational Psychology 2nd ed. (pp. 655-674). New York., NY: Macmillan.

Krumpal, I. (2013). Determinants of Social Desirability Bias in Sensitive Surveys: a Literature Review. Quality and Quantity 47 (4): 2025-2047.

Kultalahti, S. (2015). It's So Nice to be at Work!' Adopting Different Perspectives in Understanding Generation Y at Work. Doctoral Dissertation, University of Vaasa, Finland.

Lindsay, G. (2007). Educational Psychology and the Effectiveness of Inclusive Education/Mainstreaming. British Journal of Educational Psychology, 77(1), 124. 
Littrell, P. C., Billingsley, B. S., \& Cross, L. H. (1994). The effects of principal support on special and general educators’ stress, job satisfaction, school commitment, health, and intent to stay in teaching. Remedial and Special Education, 15(5), 297-310.

Malinen, O-P., \& Palmu, I. (2017). Näkökulmia yhteisopettajuuteen [Perspectives on co-teaching]. NMI Bulletin, 27(3), 41-51.

Maslow, A. (1962). Toward a Psychology of Being. Princeton, NJ: Van Nostrand.

Merriam, S. B. (2009). Qualitative research: A guide to design and implementation. San Francisco, CA: Jossey-Bass.

Mixon, D. (1972). Instead of Deception. Journal of Social Behaviour, 2, 145-178.

Moisander, J., \& Pesonen, S. (2002). Narratives of Sustainable Ways of Living: Constructing the Self and the Other as a Green Consumer. Management Decision, 40(4), 329-342.

Murawski, W.W. (2008). Five keys to co-teaching in inclusive classrooms. School Administrator, 65(8), 29-39.

Niemi, P. M., \& Hotulainen, R. (2015). Enhancing students' sense of belonging through school celebrations: a study in Finnish lower-secondary schools. International Journal of Research Studies in Education 5(2), 43-58. doi: 10.5861/ijrse.2015.1197.

Nislin, M., \& Pesonen, H. (2018). Associations of self-perceived competence, wellbeing and sense of belonging among pre- and in-service teachers encountering children with diverse needs. European Journal of Special Needs Education. https://doi.org/10.1080/08856257.2018.1533093

Osterman, K. F. (2000). Students’ need for belonging in the school community. Review of Educational Research, 70(3), 323-367.

Patton, M. Q. (2015). Qualitative Research \& Evaluation Methods. London: SAGE.

Pesonen, H. (2016). Sense of belonging for students with intensive special education needs: an exploration of students' belonging and teachers' role in implementing support (Doctoral dissertation). Retrieved from https://helda.helsinki.fi/handle/10138/159852

Pesonen, H., Kontu, E., Saarinen, M., \& Pirttimaa, R. (2015). Conceptions associated with sense of belonging in different school placements for Finnish pupils with 
special education needs. European Journal of Special Needs Education, 31(1), 59-75. doi:10.1080/08856257.2015.1087138.

Polkinghorne, D. E. (1995). Narrative configuration in qualitative analysis. In J. A. Hatch, \& R. Wisniewski (Eds.), Life history and narrative (pp. 5-23). London: Falmer Press.

Pratt, S. (2014). Achieving symbiosis: Working through challenges found in coteaching to achieve effective co-teaching relationships. Teaching and Teacher Education, 41, 1-12.

Russell, D. W., Altmaier, E., \& Van Velzen, D. (1987). Job-related stress, social support, and burnout among classroom teachers. Journal of Applied Psychology, 72(2), 269-274.

Rytivaara, A. (2012). 'We don't question whether we can do this': Teacher identity in two co-teachers’ narratives. European Educational Research Journal, 11(2), 302-313. DOI: http://dx.doi.org/10.2304/eerj.2012.11.2.304

Rytivaara, A. \& Kershner, R. (2012). Co-teaching as a context for teachers’ professional learning and joint knowledge construction. Teaching and Teacher Education, 28(7), 999-1008. DOI: 10.1016/j.tate.2012.05.006

Rytivaara, A., Pulkkinen, J. \& de Bruin, C. L. (2019) Committing, engaging and negotiating: teachers' stories about creating shared spaces for co-teaching. Teaching and Teacher Education 83, 225-235. DOI: 10.1016/j.tate.2019.04.013

Saloviita, T. (2018) How common are inclusive educational practices among Finnish teachers. International Journal of Inclusive Education, 22(5), 560-575, DOI: 10.1080/13603116.2017.1390001

Saloviita, T. \& Takala, M. (2010): Frequency of co-teaching in different teacher categories. European Journal of Special Needs Education, 25(4), 389-396. DOI: 10.1080/08856257.2010.513546

Schnorr, R. F. (1997). From enrolment to membership: “Belonging” in middle and high school classes. The Journal of the Association for Persons with Severe Handicaps, 22(1), 1-15.

Schuman, H., \& Presser, S. (1981). Questions and Answers in Attitude Surveys: Experiments on Question Form, Wording, and Context. Orlando, FL: Academic Press. 
Shin, M., Lee, H., \& McKenna, J. W. (2016). Special education and general education preservice teachers' co-teaching experiences: a comparative synthesis of qualitative research. International Journal of Inclusive Education, 20(1), 91107, doi: 10.1080/13603116.2015.1074732

Skaalvik, E., \& Skaalvik, S. (2011). Teacher job satisfaction and motivation to leave the teaching profession: Relations with school context, feeling of belonging, and emotional exhaustion. Teaching and Teacher Education, 27, 1029-1038.

Wallin, A., Koro-Ljungberg, M., \& Eskola, J. (2018). The method of empathy-based stories. International Journal of Research and Method in Education. https://doi.org/10.1080/1743727X.2018.1533937.

van der Heijden, P. G. M., van Gils, G., Bouts, J., \& Hox, J. J. (2000). A Comparison of Randomized Response, Computer-Assisted Self-Interview, and Face-to-Face Direct Questioning. Eliciting Sensitive Information in the Context of Welfare and Unemployment Benefit. Sociologial Methods \& Research, 28, 505-537.

Williams, L. J.,\& Downing, J. E. (1998). Membership and belonging in inclusive classrooms: What do middle school students have to say? Research and Practice for Persons with Severe Disabilities, 23(2), 98-110. 
Table 1. Distribution of stories between schools

\begin{tabular}{lcc}
\hline School & Story 1 (enhancing) & Story 2 (hindering) \\
\hline School A & 11 & 12 \\
School B & 8 & 7 \\
\hline
\end{tabular}


Table 2. Comparison of the main categories.

\begin{tabular}{lll}
\hline Enhancing factors & \multicolumn{1}{c}{ Dimension } & \multicolumn{1}{c}{ Hindering factors } \\
\hline $\begin{array}{l}\text { Division of work (14) } \\
\text { Planning (14) }\end{array}$ & Work practices & $\begin{array}{l}\text { Not agreeing on matters } \\
\text { (5) }\end{array}$ \\
$\begin{array}{l}\text { Shared responsibilities and } \\
\text { commitment (11) }\end{array}$ & & $\begin{array}{l}\text { Not following the agreed } \\
\text { matters (3) }\end{array}$ \\
$\begin{array}{l}\text { Respecting and trusting } \\
\text { relationship (11) }\end{array}$ & Mutual relationship & $\begin{array}{l}\text { Discomfort (7) } \\
\text { Collegial support (11) }\end{array}$ \\
$\begin{array}{l}\text { Atmosphere (6) } \\
\text { Knowing each other (3) }\end{array}$ & & \\
$\begin{array}{l}\text { Similar pedagogical thinking (7) } \\
\text { Individual strengths (5) }\end{array}$ & Individual \\
\hline
\end{tabular}




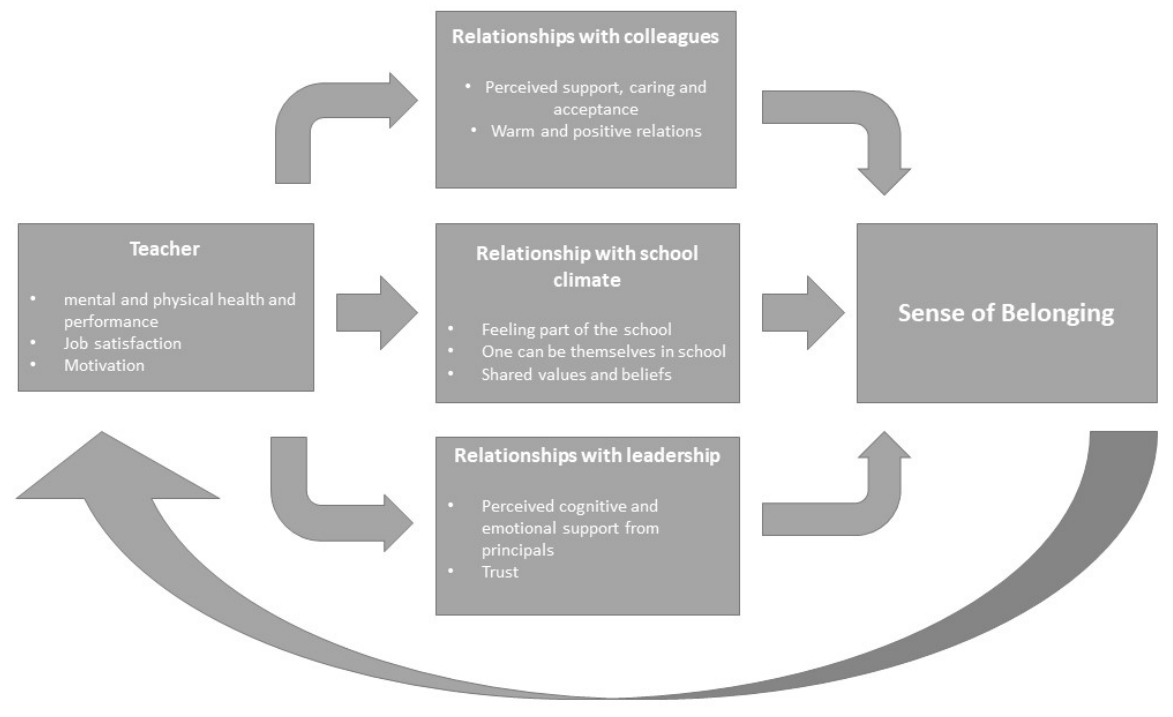

Figure 1. A model of teachers' sense of belonging depicting the association between relationships with colleagues, leadership, school climate, and sense of belonging. (Adapted from Juvonen, 2006, p. 668). 


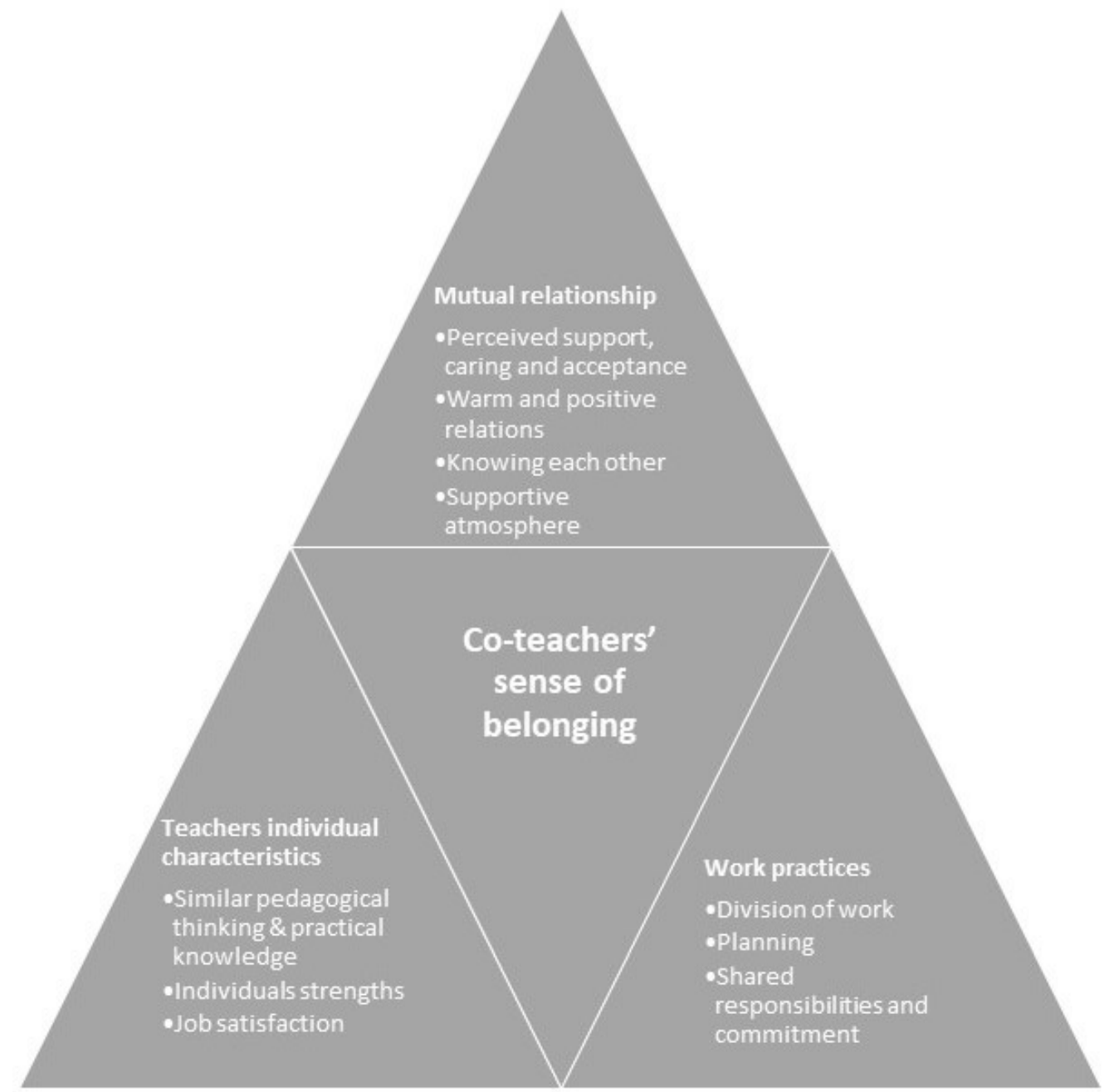

Figure 2. Dimensions associated with co-teachers' sense of belonging 